\title{
ЗАВДАННЯ СКЛАДАННЯ РОЗКЛАДУ ПЕРЕВЕЗЕННЯ В УМОВАХ НЕДОВИЗНАЧЕНОСТІ ПОКАЗНИКІВ ВАГИ ТА ОБ` СМУ ВАНТАЖУ
}

Анотація: Розглянуто завдання визначення достатньо ефективного розкладу перевезення вантажу для комплексу транспортних засобів в умовах недовизначеності показників ваги та об єму вантажу. Постановка та вирішення завдання.

Ключові слова: логістика, алгоритми пошуку маршрутів, алгоритми складання розкладів перевезень.

\section{Вступ}

У сучасному бізнесі суттєву складову мають компанії які в своїй діяльності стикаються з завданнями перевезення різного виду вантажів. Це визначило великий попит на ефективне вирішення завдань логістики для різноманітних умов виконання перевезень та стимулювало розвиток точних та наближених методів вирішення таких завдань. Проте кожна з галузей перевезень має окрім типових особистісні складові, що роблять наявні підходи не достатньо ефективними. Таким чином класична задача маршрутизації транспортних засобів з розділеним обслуговуванням (SDVRP) в кожному випадку має свої особливості.

Для обраного нами процесу діяльності що до вивозу сміття для утилізації фактичні показники як ваги так і об єму завантаженості баків (далі - Вантажних Одиниць (ВО)) замовника є суттєво недовизначеним [1]. Сдиною інформацією, якою можна скористатися для оцінювання, є дані про загальну множину ВО, що були фактично обслуговані за конкретний рейс транспортного засобу (далі ТЗ) та вантажопідйомність ТЗ. Для інших показників наявні лише дуже усереднені 3 великим розбігом значень оцінки.

Для подібних логістичних процесів рішення, що здатні ефективно виконувати завдання складання розкладу перевезень в умовах недовизначеності показників оцінювання об єкту транспортування є актуальними.

\section{Постановка задання}

Розглянемо завдання складання розкладу перевезень в умовах недовизначеності показників оцінювання для об єкту транспортування.

Нехай ми маємо теоретико-множинну модель предметної області:

$$
G=<V, Z, R, V^{\prime}, L, P, K^{\prime}, T>,
$$

(c) О.В. Гриша, Г.А. Любченко 
Міжвідомчий науково-технічний збірник «Адаптивні системи автоматичного управління» № 2' (33) 2018 де $V$ - множина ВО. ВО можуть бути встановлені по декілька в одному місці; $Z$ топологія розміщення ВО та місце доставки вантажу $v^{\prime \prime}$, що для кожного $i-2 o$ ВО $v_{i} \notin V$ встановлює географічні координати $z_{i} ; C$ - множина характеристик, наявних безпосередніх шляхів сполучення з іншими ВО та місцем доставки вантажу, що в даній роботі узагальнюються показником вартості перевезення 3 пункту $i$ в пункт $j, C=\left\{c_{i j}\right\}, i \in V, j \in V ; V^{\prime}$ - множина ВО, що повинна бути відвантажена протягом горизонту планування.

Для кожного $v_{i} \notin V$ для можливості планування потрібна оцінка показника ваги $w_{i}=\left[w_{i \max } ; w_{i \min }\right] ;$ У якості такої оцінки ми можемо використати лише мінімальну та максимальну статистичну оцінку кількості ВО обслугованих ТЗ певного типу за один рейс.

$L$ - наявний парк Т3 з параметрами цих засобів та кількістю одиниць кожного виду. Кожному транспортному засобу відповідає один водій;

$P$ - тривалість робочої зміни водіїв ТЗ;

$R$ - розклад обслуговування $V$ ВО на зміну;

$K^{\prime}$ - множина рейсів (кластерів) які заплановані у розкладі на зміну для ycix T3 $. R=\cup k_{j}, k_{j} \in K^{`}$;

$T$ - множина показників тривалості виконання змінного завдання кожною машиною(водієм) $t_{l} \in T, t_{l}=\sum_{k \in K^{\prime}, l \in L} t_{k l}$.

Потрібно виконати завдання складання розкладу перевезень на зміну так, щоб різниця у навантаженні на кожного з водіїв, відхилення реально перевезеного $V^{\prime}$ від замовленого $V^{\prime}$ об єму перевезень на зміну та вартість виконання всього об`єму перевезень були мінімальними при умові не перевищення тривалості робочої зміни водіїв. Тобто

$$
\begin{gathered}
\arg \underset{t_{l}, t_{l} \in T, l, l \in L}{\min \max }\left|t_{l}-t_{l}\right| ; t_{l}=f(R), t_{l} \leq P \text { для } \forall l \in L \\
C=\sum_{i \in V^{\prime}} \sum_{j \in V^{\prime}} \sum_{l \in L c} c_{i j l} \rightarrow \min \\
\left(/ V^{\prime} /-/ V^{`}=f^{\prime}(R) /\right) \rightarrow \min
\end{gathered}
$$

Обмеження:

$$
\begin{aligned}
& \sum_{i \in V^{\prime}} \sum_{l \in L c} x_{i j l} \geq 1, j=1,2, . .,\left|V^{`}\right| ; \\
& \sum_{i \in V^{\prime}} x_{i j l}=\sum_{i \in V^{\prime}} x_{j i l}, j=1,2, . .,\left|V^{`}\right|, l=1,2, . .,|L| ; \\
& u_{i l k}-u_{j l k}+n x_{i j l} \leq\left|V^{`}\right|-1, j=1,2, . .,\left|V^{\prime}\right|, l=1,2, . .,|L|, k=1,2, . .,|K|
\end{aligned}
$$


Міжвідомчий науково-технічний збірник «Адаптивні системи автоматичного управління» № 2' (33) 2018

$$
w_{i} \sum_{l \in L, i \in k_{n}, j \in k_{n}} x_{i j l} \leq W, n=1,2, . .,|K|
$$

де $\quad x_{j i l}=1$ якщо Т3 lïде напряму від ВО $i$ до ВО $j ; u_{i l k}-$ позиція ВО $i$ у маршруті для Т3 $l$ у $k$-му рейсі.

Специфічні умови завдання: початковий пункт, місце призначення вантажу та кінцевий пункт прибуття однакові для усіх Т3. Наразі усі ТЗ мають однакову місткість та ВО мають однаковий тип. Один ВО може бути обслугованим лише одним ТЗ. Оскільки кожен рейс закінчується відвантаженням у одну точку призначення, то тільки ця точка може повторюватися у маршруті рейсу двічі. Перевантаження Т3 не припустимо і момент повного завантаження визначається динамічна тільки в процесі обслуговування. Матриця відстаней між ВО задовольняє нерівності трикутника.

Визначення: рейсом ТЗ будемо називати один цикл обслуговування ВО-в від моменту розвантаження/виїзду з гаража на початку зміни (початкова точка рейсу) до моменту відвантаження /заїзду в гараж в кінці зміни (кінцева точка рейсу).

\section{Вирішення задачі}

В поставленій задачі залежність вартості перевезень та відхилення від плану за наявне вікно виконання перевезень $€$ алгоритмічною, тобто ми не маємо недиференційованої функції $t_{l}=f(R)$ та $V^{\prime \prime}=f^{\prime}(R)$. Оскільки на етапі складання розкладу невідома вага та об єм вмісту ВО, тому невідомо скільки ВО може бути обслуговано за один рейс відвантаження та враховуючи комбінаторну складність задачі комівояжера, скористаємося пошуком ефективного евристичного рішення.

Ефективне розв'язання складних комбінаторних задач або задач із недиференційованою цільовою функцією має базуватись на поєднанні методів локального та глобального пошуку. В цій ситуації скористаємося методом вектору спаду Сергієнка I.B. [2] та деякими евристичними алгоритмами.

\section{Послідовність етапів вирішення завдання}

1. Розбиваємо заплановану множину ВО на кластери. Розмір кожного кластера відповідає максимальній місткості Т3. Для цього :

а) Відсортовуємо всі вершини графу за віддаленістю від початкової вершини - обрано для поточного варіанту рішення місце відвантаження;

b) Обираємо найбільш віддалену вершину та зафіксовуємо іiі;

c) Сортуємо весь масив за ступенем наближеності до зафіксованої вершини;

d) Відрізаємо перші S ( що дорівнює максимальній місткості Т3) $\mathrm{BO}$ від початкового масиву та зберігаємо їх як перший кластер. 
Міжвідомчий науково-технічний збірник «Адаптивні системи автоматичного управління» № 2' (33) 2018

е) Повторювати кроки 1-4 зі зменшеним масивом доки всі елементи не будуть опрацьовані.

2. Для наявної множини кластерів визначаємо послідовність обходу та призначення транспортного засову наступним чином:

а) Обираємо Т3, що першим звільнився після виконання рейсу. Для Т3, які мають однаковий час звільнення вибираємо випадково.

b) Формуємо наступний кластер для рейсу обслуговування за критерієм близькості до попереднього та віддаленості від точки призначення.

с) Якщо протягом попередніх рейсів виявилися ВО, що не були обслуговані, вони додаються до кластеру.

3. Визначаємо достатньо ефективний маршрут обслуговування ВО в кластері. Визначення маршруту у кластері $\epsilon$ задачею типу комівояжера i рішення таких задач $є$ NP трудним. Знаходження точного рішення задачі у такій постановці не може бути практично реалізоване, тому автори скористався пошуком достатньо ефективного наближеного рішення задачі. Скористаємося гібридним алгоритмом [3], що грунтується на наступному - перегляд перестановок методом локального пошуку ; для кожної перестановки застосування наближеного алгоритму отримання набору маршрутів.

Загальна схема алгоритму:

а) Генерація стартової послідовності. У якості початкового рішення беремо маршрут рейсу попередньої зміни, який має найбільший перетин ВО з поточним кластером з додаванням до перетину нових ВО.;

b) Пошук з заборонами;

c) Зміна декодеру;

d) Спуск по околам ;

е) Якщо вичерпано максимальну кількість ітерацій- виведення рекорду;

f) Зміна декодера. На 2.

Локальний спуск по черзі околиць

а) Регулярна зміна околиці з метою знаходження спільної локального оптимуму для всіх околиць;

b) shift, swap, 2-opt, exchange, k-split (поліноміальної потужності),

c) Використовуємо метод динамічного програмування в якості процедури декодування.

Процедура пошуку з заборонами

a) Застосовується для диверсифікації пошуку з метою змінити район пошуку;

b) Використовуються рандомізовані shift, swap i 2-opt околиці.

c) Як заборони, застосовуються пари ВО; 
d) Використовується жадібний метод декодування послідовностей;

е) Критерій зупинки - максимальне число ітерацій.

4. Після обслуговування останнього ВО рейсу стає відомим (водій сповіщає) про множину обслугованих ВО.

5. Якщо усі ВО обслуговані ТЗ повертається у гараж і алгоритм закінчує роботу.

6. Якщо вікно обслуговування закінчено (закінчується зміна) і не всі ВО обслуговані, вони заносяться до пріоритетного списку обслуговування і для них на початку наступної зміни формується окремий розклад для першочергового обслуговування. Першочергове обслуговування виконується також за цим алгоритмом. Алгоритм закінчує роботу.

7. Через те, що алгоритм дозволяє здійснити розрахунок плану перевезень в оперативний час, а його вартість суттєво нижча за вартість перевезень, то перерахунок плану здійснюється при закінченні кожного рейсу. Тому, якщо вікно обслуговування не закінчено (закінчується зміна) і не всі ВО обслуговані, переходимо до пункту 1.

\section{Висновки}

Поданий метод вирішення специфічної задачі типу комівояжера дозволяє отримати прийнятне рішення в заданому проміжку часу проходження екземпляру процесу діяльності, дозволяє враховувати попередні результати складання маршрутів і може бути використаним в умовах недовизначеності показника наповненості вантажних одиниць обслуговування.

\section{Список використаних джерел}

1. Нариньяни А. С. Недоопределённость в системах представления и обработки знаний.//Изв. АН СССР. Техн.кибернетика. - 1986. - №5.

2. Сергиенко И.В., Лебедева Т.Т., Рощин В.А. Приближенные методы решения задач дискретной оптимизации. // Киев: Наук. Думка, 1980. -276 с.

3. Хмелев А.В. Алгоритмы локального поиска для задач маршрутизации транспортных средств. [Електронный ресурс] / //http://www.math.nsc.ru/LBRT/k5/Kochetov/ Khmelev_avtoref.pdf. 